\title{
ANALISIS KEMAMPUAN BERPIKIR KRITIS MATEMATIS SISWA SMK PADA MATERI BARISAN DAN DERET
}

\author{
Eka Noviana Kharisma \\ Pendidikan Matematika IKIP Siliwangi Bandung
}

\begin{abstract}
This study aims to analyze the critical thinking skills of students of the vocational high school in mathematics concept of sequence and series. The method used in this research is descriptive qualitative with limited subjects that are 3 students of the vocational high school in Bandung district with high, medium and low classification. The main instrument in this study is the researchers themselves, critical thinking mathematical skill tests and interview guidelines. Results of this study show that the critical thinking skill mathematically owned by vocational students in Bandung district is still relatively low, it is based on written tests and interview with students.
\end{abstract}

Keywords: Critical thinking; Sequence and series

\section{PENDAHULUAN}

Menurut Purwanto (2007), berpikir adalah salah satu keaktifan pribadi manusia yang menghasilkan penemuan terarah kepada suatu tujuan. Manusia berpikir untuk menemukan pemahaman/pengertian yang dikehendakinya. Selanjutnya menurut Trianto, berpikir adalah kemampuan untuk menganalisis, mengkritik, dan mencapai kesimpulan berdasar pada inferensi atau pertimbangan yang seksama (Purmawidyani, 2017).

Johnson menyatakan bahwa berpikir kritis dan kreatif matematis memungkinkan siswa untuk mempelajari permasalahan secara sistematis, menghadapi berbagai tantangan dengan cara yang terorganisasi, menyusun pertanyaan inovatif, serta merancang permasalahan yang relatif baru (Hidayat, 2012). Sedangkan Ennis, menyatakan berpikir kritis matematis merupakan berpikir secara beralasan dan reflektif yang menitikberatkan pada pengambilan keputusan mengenai sesuatu yang harus dipercayai atau dilakukan (Hendriana, Rohaeti, \& Sumarmo, 2017). Berpikir kritis berhubungan dengan lima ide kunci yaitu praktis, reflektif, logis, kepercayaan, dan aksi.

Fisher (2009) mengemukakan bahwa kemampuan berpikir kritis adalah kemampuan menginterpretasi, menganalisis, dan mengevaluasi gagasan dan argumen. Berdasarkan informasi yang diterima kemudian diperiksa dan dibandingkan dengan pengetahuan dan pemahaman yang dimiliki sebelumnya sehingga mampu memberikan kesimpulan terhadap informasi tersebut dengan disertai asumsi yang tepat. Berpikir kritis matematis merupakan dasar proses berpikir untuk menganalisis argumen dan 
memunculkan gagasan terhadap tiap makna untuk mengembangkan pola pikir secara logis (Jumaisyaroh, 2014).

Menurut Sumarmo, pentingnya keterampilan berpikir kritis yang ditekankan kepada siswa didukung oleh visi pendidikan matematika yang mempunyai dua arah pengembangan, yaitu dapat memenuhi kebutuhan masa kini dan masa mendatang (Istianah, 2013). Visi pertama untuk kebutuhan masa kini adalah pembelajaran matem atika yang mengarah pada pemahaman beberapa konsep yang diperlukan untuk memecahkan masalah matematika dan ilmu pengetahuan lain. Visi kedua untuk kebutuhan masa mendatang adalah pembelajaran matematika memberikan kemampuan penalaran yang logis, sistematis, kritis, dan cermat serta berpikir objektif dan terbuka, yang sangat diperlukan dalam kehidupan sehari-hari serta untuk menghadapi masa depan yang selalu berubah.

Hasil studi internasional mengenai prestasi matematika siswa yang dilakukan Trend in International Mathematics and Science Study (TIMSS) pada tahun 2011 menunjukkan bahwa Indonesia berada di peringkat ke-38 dari 42 negara peserta dengan rata-rata 386 dari skor rata-rata internasional 500. Sedangkan data Programme for International Student Assessment (PISA) tahun 2012, Indonesia berada di peringkat ke-64 dari 65 negara. Berdasarkan hasil studi TIMSS dan PISA menunjukkan bahwa penguasaan kemampuan berpikir kritis matematis siswa masih rendah (Mahmuzah, Ikhsan, \& Yusrizal, 2014).

Konsep barisan dan deret sangat penting peranannya dalam kehidupan sehari-hari maupun dalam ilmu pengetahuan dan teknologi. Pemahaman dalam materi ini akan membantu siswa dalam menyelesaikan masalah matematika yang ada pada kehidupan nyata. Misalnya dalam mengukur kecepatan kendaraan pada spedometer yang mana pada spedometer akan memuat beberapa barisan angka yang memiliki pola tertentu membentuk sebuah barisan aritmatika. Selain itu, dalam ilmu ekonomi materi tersebut dapat digunakan dalam menghitung pertumbuhan penduduk dan pangan, mengukur biaya produksi dan pendapatan, serta menghitung bunga majemuk dalam dunia perbankan. 


\section{METODE PENELITIAN}

Metode yang digunakan pada penelitian ini adalah deskriptif kualitatif yang bertujuan untuk mendeskripsikan hasil analisis kemampuan berpikir kritis matematis pada materi barisan dan deret. Subjek pada penelitian ini adalah 3 orang siswa SMK kelas XI di Kabupaten Bandung dengan klasifikasi berkemampuan tinggi, sedang, dan rendah berdasarkan nilai rapor matematika. Instrumen utama dalam penelitian ini adalah peneliti sendiri, tes kemampuan berpikir kritis matematis sebanyak 7 soal serta pedoman wawancara.

\section{HASIL DAN PEMBAHASAN}

Hasil analisis data kemampuan berpikir kritis matematis pada materi barisan deret menunjukkan bahwa didapat hasil yang berbeda dari 3 subjek tersebut berbeda. Adapun soal-soal dalam instrumen ini adalah sebagai berikut:

1. Beberapa persegi dikelompokkan dan disusun sehingga setiap kelompok yang tersusun membentuk persegi yang baru seperti berikut:
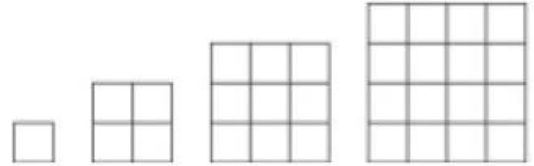

Dapatkah kamu temukan susunan persegi berikutnya?

2. Diketahui $a+(a+1)+(a+2)+\cdots+50=1139$. Jika a bilangan bulat positif, maka nilai $a=\cdots$

3. Perhatikan pola barisan bilangan berikut!

$1,3,7,9, \ldots$

$27,9,3,1, \ldots$

Apakah barisan tersebut termasuk barisan aritmatika atau barisan geometri? Tentukan suku ke-10 dari barisan tersebut!

4. Selidiki apakah jumlah $n$ bilangan asli pertama, yaitu $1+2+\cdots+n$ sama dengan $\frac{n(n+1)}{2}$ !

5. Untuk memeriksa sebuah barisan merupakan barisan geometri apakah cukup hanya menentukan rasio dua suku berurutan?

6. Setiap hari Ida menabungkan sisa uang jajannya. Pada hari pertama Ida menabung sebesar Rp. 2500,00. Bagaimana cara mengetahui banyaknya uang Ida yang telah ditabung selama 1 minggu?

7. Tentukan empat suku pertama dari barisan tersebut, jika rumus umum suku ke- $n$ diketahui $U n=3 n+1$ ! 


\section{Merumuskan Masalah}

Siswa 1 (kemampuan tinggi)

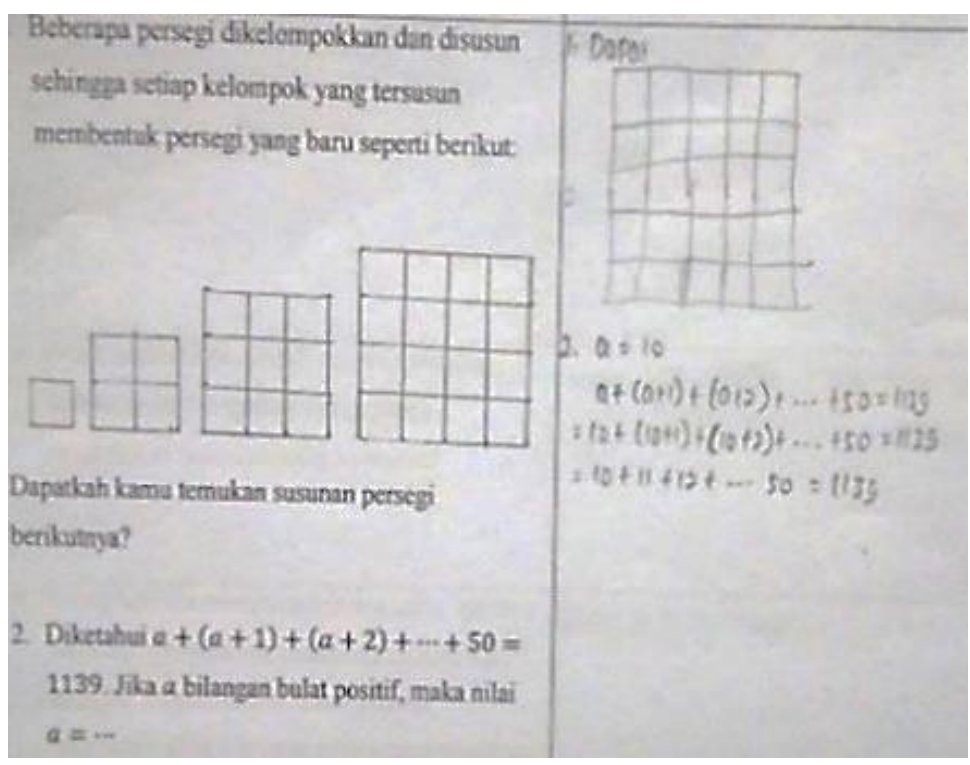

Gambar 1. Jawaban S1 Soal 1 dan 2

Siswa 1 (S1) dapat menjawab soal nomor 1 dengan tepat, meskipun tidak ada penjelasan pada jawaban. Namun, S1 sudah dapat menggambar pola selanjutnya dari persegi tersebut. Sedangkan pada soal nomor 2, S1 hanya bisa menebak-nebak saja dan tidak menjelaskan bagaimana proses yang relevan untuk menemukan jawaban. Berikut hasil wawancara dengan siswa I (S1):

G : "Mengapa kamu bisa menjawab bahwa susunan persegi yang selanjutnya adalah seperti itu?"

S1 : "Aku langsung liat aja bu untuk persegi yang pertama itu kan 1, terus persegi yang kedua itu 4, persegi yang ketiga ada 9, dan persegi yang terakhir adalah 16. Jadi kan pasti polanya itu adalah $1 \times 1,2 \times 2,3 \times 3$ dan 4x4, makanya susunan persegi yang kelima itu adalah 25."

G : "Bagaimana kamu bisa menentukan bahwa jawaban nomor 2 seperti itu?"

S1 : "Aku cuma nebak aja bu, soalnya aku lupa lagi cara nyari a itu gimana"

$G \quad$ : "Padahal kamu hanya tinggal mensubstitusi yang diketahui aja ke dalam rumus barisan, coba nanti dilihat lagi ya bukunya." 
Siswa 2 (kemampuan sedang)

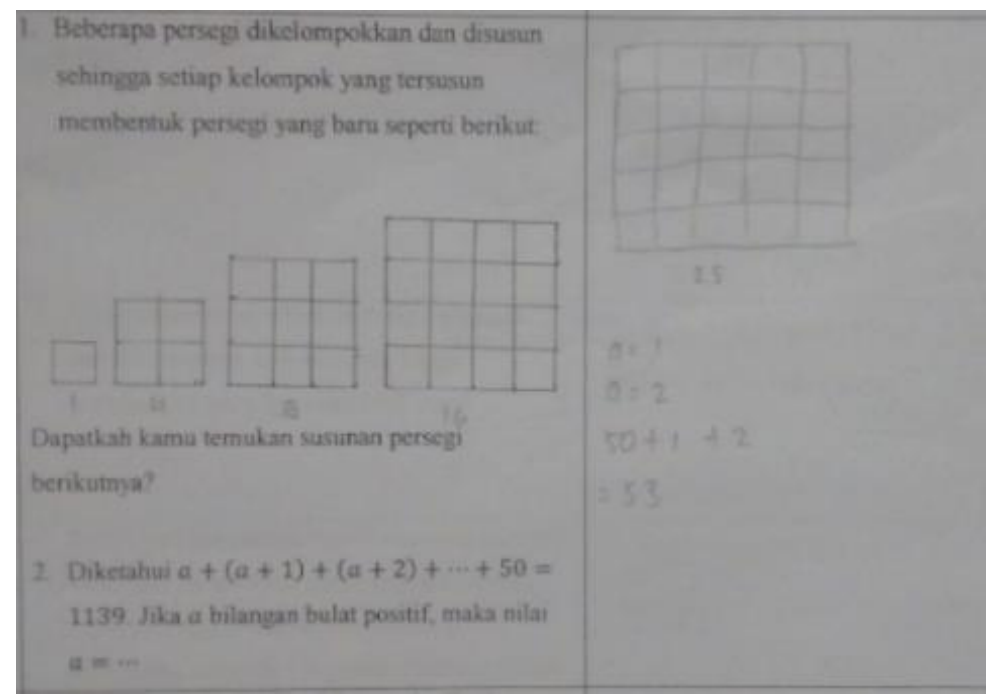

Gambar 2. Jawaban S2 Soal 1 dan 2

Siswa 2 (S2) juga dapat menjawab soal nomor 1 dengan tepat, namun hanya dapat menggambar pola selanjutnya dari persegi tersebut. Sedangkan pada soal nomor 2, S2 hanya bisa menebak jawaban dari nilai $a$, tetapi tidak dijelaskan bagaimana cara yang digunakan untuk menemukan nilai $a$ tersebut. Berikut adalah hasil wawancara dengan S2:

G : "Mengapa kamu dapat menjawab bahwa susunan persegi selanjutnya adalah 25?"

S2 : "Aku pertamanya hitung dulu setiap susunan perseginya, terus aku tambahin deh di sisi kanannya 5 dan atasnya 5 jadi hasilnya adalah 25.

$G \quad: \quad$ "Lalu mengapa soal nomor 2 kamu menjawab a $=1$ dan $a=2$ ?"

S2 : "Sebenarnya aku lupa lagi bu cara ngitungnya gmna jadi aja aku nagasal jawabnya."

$G \quad$ : "Untuk soal nomor 2, seharusnya kamu hanya tinggal mencari nilai a dengan rumus barisan yang biasanya digunakan, jadi nanti akan ketemu jawabannya"

\section{Siswa 3 (kemampuan rendah)}

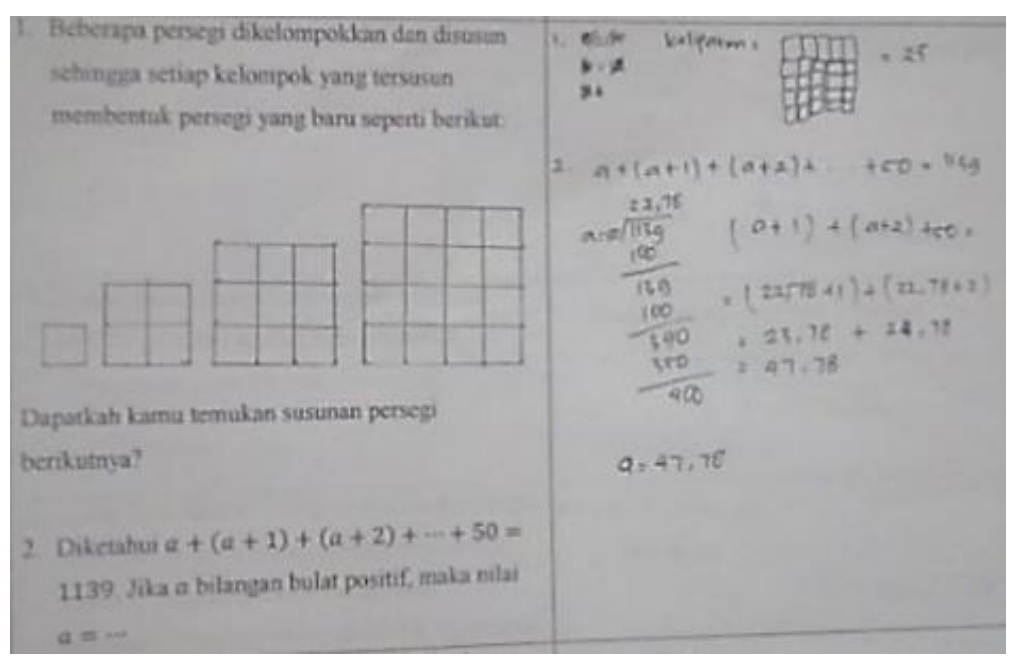

Gambar 3. Jawaban S3 Soal 1 dan 2 
Siswa 3 (S3) menjawab soal nomor 1 dengan tepat, namun penjelasan S3 bahwa soal tersebut berupa kelipatan kurang tepat karena soal ini merupakan soal untuk menetukan pola bilangan. Sedangkan untuk soal nomor 2, S3 mencoba untuk menghitung dan mencari nilai $a$. Namun, cara yang digunakannya kurang relevan dengan apa yang diharapkan sehingga jawaban siswa tersebut salah. Berikut adalah hasil wawancara dengan S3:

G : "Mengapa kamu berpendapat bahwa soal nomor 1 ini merupakan suatu kelipatan?"

S3 : "Ya sudah terlihat bu dari jumlah perseginya. 1 terus 4 terus 9... Eh bukan ketang bu bukan kelipatan”

G : "Nah jadi seharusnya jawabannya itu bukan kelipatan ya, tapi kuadrat coba dilihat lagi polanya. Lalu kenapa untuk soal nomor 2 kamu menjawab seperti itu?"

S3 : "Oh iya bu, soalnya tadi kepikirannya itu kelipatan, kalau soal nomor 2 aku bingung bu itu mah aku ngasal bu soalnya lupa rumus jadi aja a nya bentuknya desimal"

\section{Memberikan Argumen}

\section{Siswa 1 (kemampuan tinggi)}

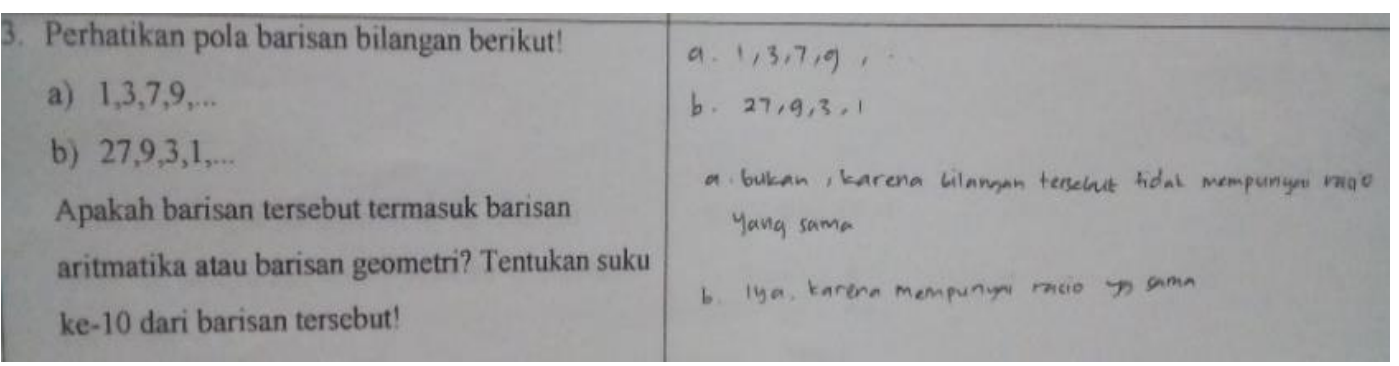

Gambar 4. Jawaban S1 Soal 3

S1 sudah dapat membedakan dengan baik antara barisan aritmatika dengan barisan geometri. Namun, untuk menemukan suku ke-10 dari masing-masing barisan, siswa masih mengalami kekeliruan karena rumus yang digunakan kurang tepat. Hal ini disebabkan kurang telitinya S1 melihat susuan bilangan tersebut. Berikut hasil wawancara dengan S1:

G : "Kamu sebenarnya sudah bisa membedakan mana barisan aritmatika dan mana yang merupakan barisan geometri, hanya pada penyelesaiannya masih terdapat kekeliruan, bisa dijelaskan kenapa kamu menjawab dengan rumus seperti itu?"

S3 : "Aku mah yakin banget bu ini jawabanya udah bener da."

$G \quad$ : "Sebenarnya untuk poin yang a kamu harus memperhatikan lagi polanya jadi rumusnya tidak akan seperti itu, sedangkan untuk poin b kamu sudah benar rumusnya hanya pada perhitungannya ada yang masih keliru” 
Siswa 2 (kemampuan sedang)

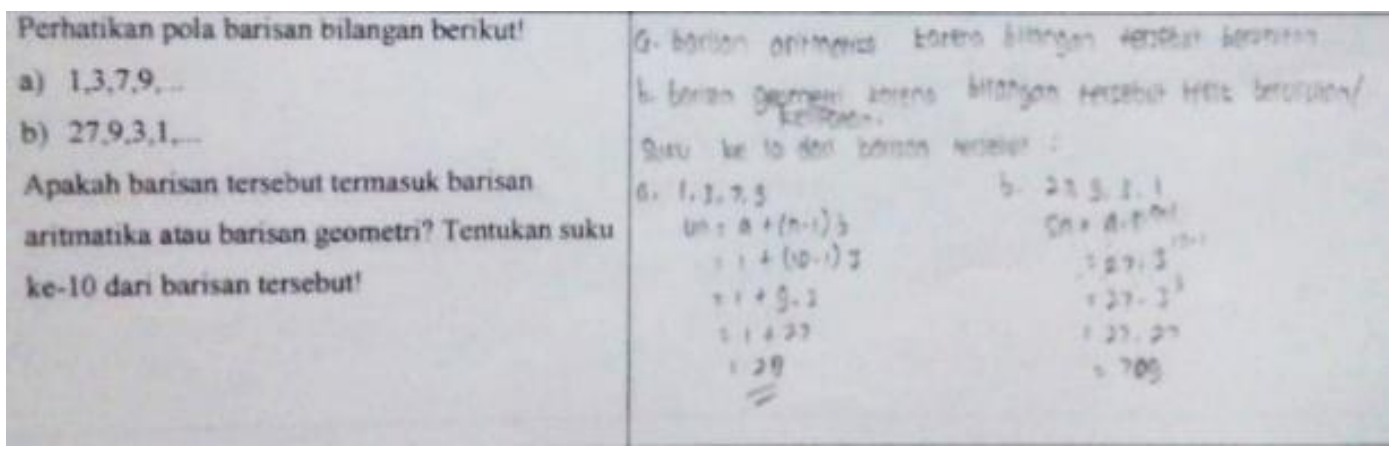

Gambar 5. Jawaban S2 Soal 3

S2 masih belum dapat membedakan barisan geometri dengan barisan aritmatika, sehingga kedua jawabannya adalah barisan geometri. Selanjutnya S2 belum dapat menghitung suku ke-10 dari barisan tersebut dengan menggunakan rumus yang tepat, melainkan S2 hanya menghitung manual dan jawabannya pun masih kurang tepat. Berikut hasil wawancara bersama S2:

G : "Mengapa kamu belum bisa membedakan antara barisan ariematika dan barisan geometri?"

S2 : "Iya bu aku masih suka ketuker antara barisan aritmatika dan barisan geometri, jadi aku kira dua-duanya itu barisan geometri."

$G \quad:$ "Barisan aritmatika itu adah barisan yang diperoleh dari menjumlahkan atau mengurangkan suku sebelumnya dengan bilangan yang tetap. Sedangkan barisan geometri adalah barisan yang diperoleh dengan mengalikan atau membagi suku sebelumnya dengan bilangan yang tetap"

Siswa 3 (kemampuan rendah)

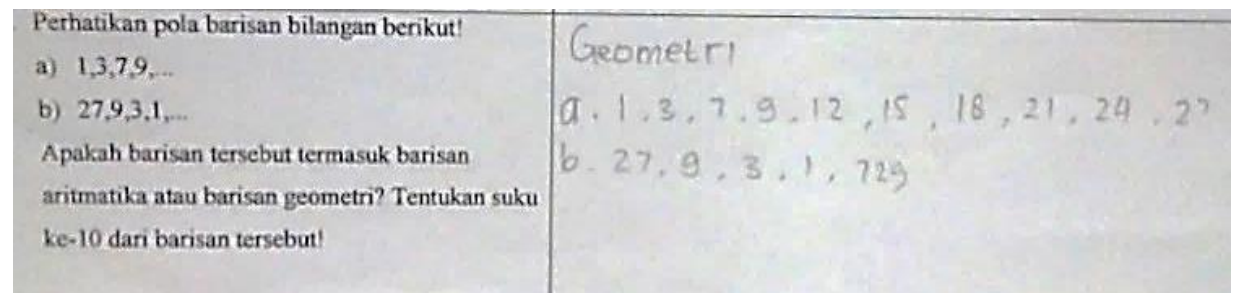

Gambar 6. Jawaban S3 Soal 3

S3 menjawab soal ini dengan kurang tepat, dimana S3 tidak bisa membedakan antara barisan aritmatika dengan barisan geometri dan S3 juga tidak bisa menentukan suku ke-10 dari barisan tersebut. Kemungkinan S3 ini kurang teliti dalam membaca soal sehingga tidak bisa menjawab soalnya dengan baik. Berikut adalah wawancara dengan S3:

G : "Mengapa kamu menjawab soal nomor 3 ini seperti itu? Coba dibaca lagi soalnya dengan baik! Lalu kenapa kamu tidak mencari suku ke-10 dari barisan tersebut?" 
S3 : "Oh iya bu aku kurang teliti membaca soalnya, aku kira soalnya itu barisan geometri atau bukan makanya aku jawabnya gitu bu. Aku lupa bu rumusnya itu seperti apa jadi aku gak jawab bu takut salah"

\section{Menentukan Deduksi dan Induksi}

Siswa 1 (kemampuan tinggi)

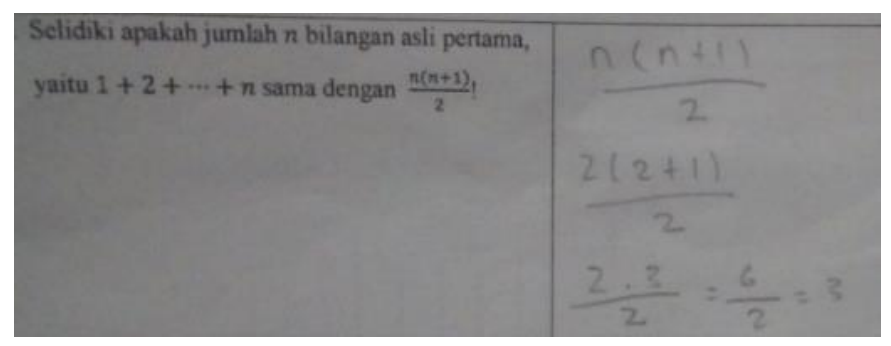

Gambar 7. Jawaban S1 Soal 4

S1 masih belum bisa menyelidiki jawaban yang relevan dengan pertanyaan tersebut. S1 hanya bisa menulis bahwa pernyataan itu sama, tetapi tidak menunjukkan di titik mana kesamaan antara dua pernyataan tersebut. Berikut adalah hasil wawancara dengan S1:

G : "Mengapa kamu menjawab soal ini dengan mengatakan bahwa kedua pertanyaan adalah sama?"

S3 : "Soalnya aku bingung bu harus digimanain itu jawabnya."

$G \quad$ : "Memang untuk soal yang ini perlu dilakukan beberapa langkah untuk menunjukkan bahwa kedua pernyataan itu sama"

Siswa 2 (kemampuan sedang)

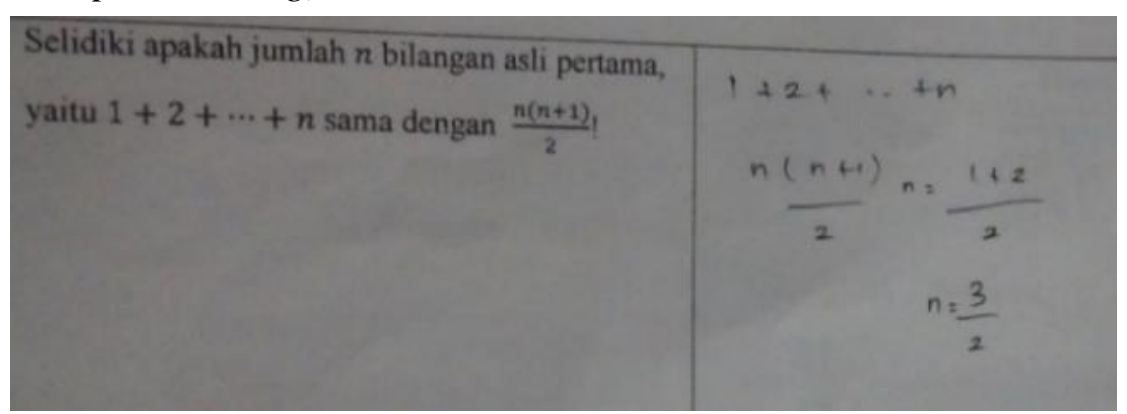

Gambar 8. Jawaban S2 Soal 4

$\mathrm{S} 2$ menjawab dengan mensubstitusikan angka 2 ke dalam rumus, tetapi tidak bisa menunjukkan apakah kedua pernyataan itu sama atau berbeda. Berikut ini adalah hasil wawancara dengan S2:

G : "Mengapa kamu bisa menentukan bahwa jawaban soalnya seperti itu?"

S2 : "Aku mah cuma coba-coba aja bu masukin angkanya 2, soalnya aku gatau sebenernya jawabannya itu caranya gimana."

G : "Jawabannya itu memiiki beberapa langkah pengerjaan, jadi nanti kamu coba pahami lagi ya tentang soal-soal seperti ini”" 
Siswa 3 (kemampuan rendah)

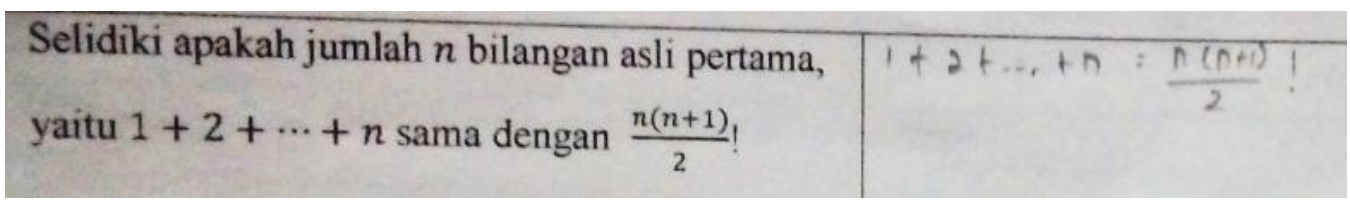

Gambar 9. Jawaban S3 Soal 4

S3 menjawab soal tersebut dengan kurang tepat. Hal ini terlihat dari jawaban S3, dimana terdapat kesalahan perhitungan sehingga jawabannya kurang tepat dan belum menunjukkan apakah kedua pernyataan ini sama atau berbeda. Berikut hasil wawancara dengan S3:

G : "Bagaimana caramu sehingga mendapatkan jawaban seperti itu?"

S3 : "Aku mah sebenernya bingung bu gimana jawabnya, aku coba aja masukin angkanya. Tapi aku mah yakin bu itu teh salah da."

G : "Iya sebenarnya untuk soal sepeti ini kamu harus dapat menunjukkan kesamaan kedua pernyataan tersebut dengan melakukan beberapa langkah yang relevan."

\section{Melakukan Evaluasi}

Siswa 1 (kemampuan tinggi)

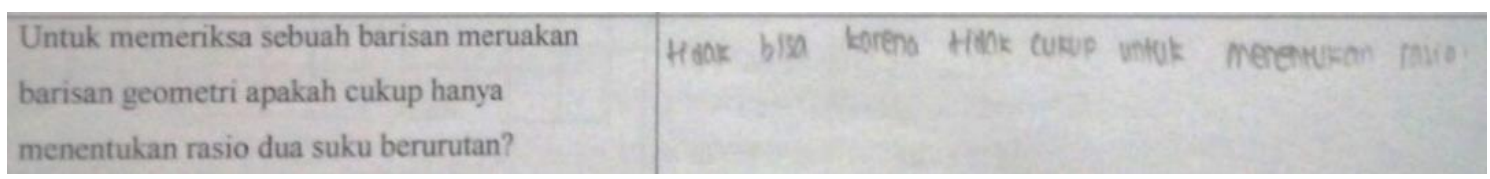

\section{Gambar 10. Jawaban S1 Soal 5}

$\mathrm{S} 1$ belum bisa memahami dengan baik materi barisan dan deret. Hal ini terlihat dari hasil jawaban siswa pada soal tersebut. Seharusnya jawaban yang tepat adalah "benar" hanya dengan menentukan rasio dari dua suku yang berurutan. Berikut adalah hasil wawancara dengan S1:

G : "Apa yang menjadi kesulitanmu dalam menjawab soal tersebut?"

S1 : "Aku sebenarnya kurang paham bu tentang ini tapi susah mengungkapkan kata-katanya " " $u$, terus aku juga lupa ini bisa atau enggak bu makanya aku jawab aja enggak bisa"

$G \quad$ : "Padahal ini jawabannya gampang tinggal kita kembalikan saja ke definisi dari barisan geometri sehingga akan nampak nanti jawabannya"

Siswa 2 (kemampuan sedang)

\begin{tabular}{|c|c|}
\hline $\begin{array}{l}\text { Untuk memeriksa sebuah barisan meruakan } \\
\text { barisan geometri apakah cukup hanya } \\
\text { menentukan rasio dua suku berurutan? }\end{array}$ & $\begin{array}{l}\text { Tidak, kareno rasio } 2 \text { suku berurutar hasilnys } \\
\text { tadak bise dihitung }\end{array}$ \\
\hline
\end{tabular}

Gambar 11. Jawaban S2 Soal 5 
S2 tidak jauh berbeda dengan S1 karena menjawab "tidak", sehingga dapat disimpulkan bahwa S2 belum dapat memahami konsep dari barisan dan deret dengan baik. Berikut adalah hasil wawancara dengan S2:

G : "Apa yang menjadi kendala kamu saat menjawab soal tersebut?"

S2 : "Menurut aku mah bu ini enggak bisa karena kalau sukunya cuma dua enggak akan bisa dihitung hasilnya."

G : "Coba dibaca lagi ya bukunya tetang barisan geometri supaya kamu bisa paham dengan baik soal-soal seperti ini."

Siswa 3 (kemampuan rendah)

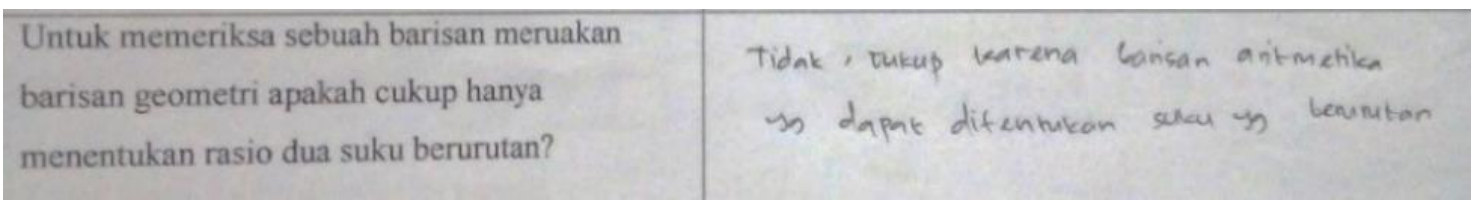

Gambar 12. Jawaban S3 Soal 5

S3 juga tak jauh berbeda dengan S1 dan S2. Jadi, untuk soal-soal evaluasi seperti ini siswa masih merasa kesulitan untuk menjawabnya. Hal ini terlihat dari semua jawaban siswa yang menjawab tidak bisa. Berikut adalah hasil wawancara dengan S3:

G : :Apa yang menjadi kesulitanmu dalam menjawab soal tersebut?"

S3 : "Setahu aku memang gabisa bu karena yang bisa ditentukan rasionya itu adalah barisan aritmatika."

G : "Sebenarnya barisan geometri itu bisa diperiksa hanya dengan menetukan rasio dua suku, coba nanti dilihat lagi ya bukunya supaya tidak tertukar."

\section{Mengambil Keputusan}

Siswa 1 (kemampuan tinggi)

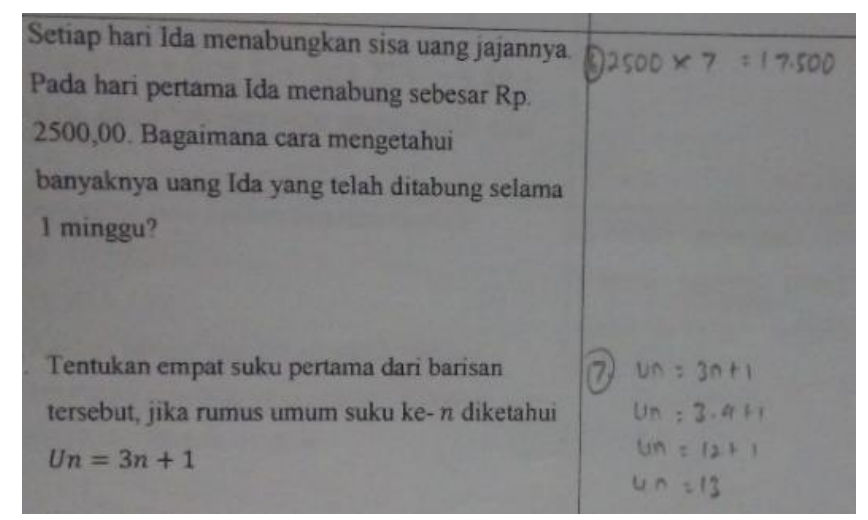

Gambar 13. Jawaban S1 Soal 6 dan 7

Pada soal-soal ini, S1 sudah dapat menjawab soal nomor 6 dengan baik, tetapi belum secara rinci dijelaskan menggukan konsep barisan dan deret. Sedangkan untuk 
nomor 7, S1 hanya bisa menjawab suku keempatnya saja dan tidak bisa menjawab suku kesatu, kedua dan ketiganya. Berikut adalah hasil wawancara yang dilakukan dengan S1:

G : :Bagaimana kamu bisa menjawab soal-soal tersebut?"

S1 : "Kalau soal nomor 6 mah gampang bu tinggal dikaliin aja, kalau nomor 7 mah tinggal dimasukin aja ke rumusnya."

G : "Tapi seharusnya nomor 6 itu menjawabnya harus dengan konsep barisan dan deret, sedangkan nomor 7 itu harus dicari suku ke-1, ke-2, ke-3, dan ke-4."

Siswa 2 (kemampuan sedang)

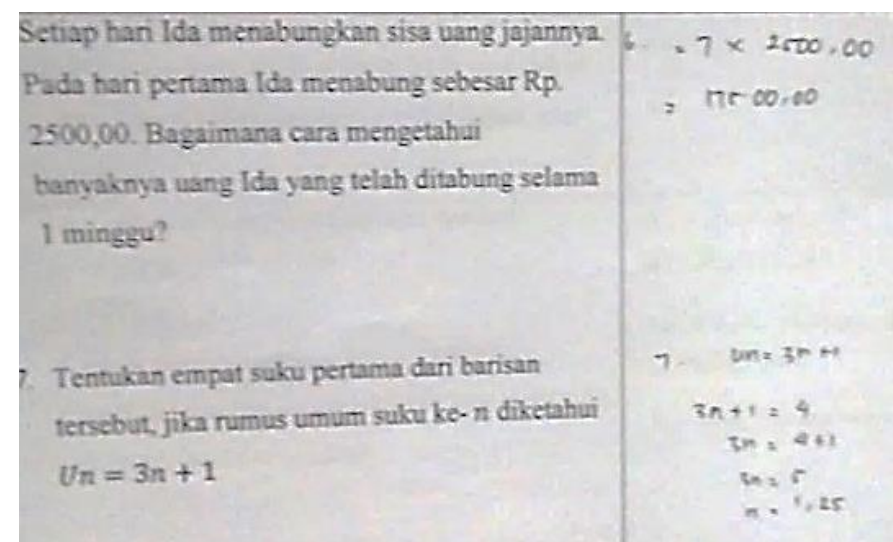

Gambar 14. Jawaban S2 Soal 6 dan 7

S2 menjawab soal nomor 6 dengan baik, tetapi tidak menerapkan konsep barisan dan deret dengan baik. Untuk soal nomor 7, S2 salah dengan mensubstitusi angka pada soal nomor 6 ke soal nomor 7 sehingga jawaban siswa masih kurang tepat. Berikut adalah hasil wawancara dengan S2:

G : : "Apa yang menjadi kesulitanmu dalam menjawab soal nomor 6? Mengapa soal nomor 7 kamu mensubstitusi nilai n dengan 17500?”

S2 : "Kalau soal nomor 6 mah gampang bu tinggal dikaliin aja langsung deh dapet jawabannya, kalau soal nomor 7 aku salah masukin angkanya gak fokus baca soalnya."

Siswa 3 (kemampuan rendah)

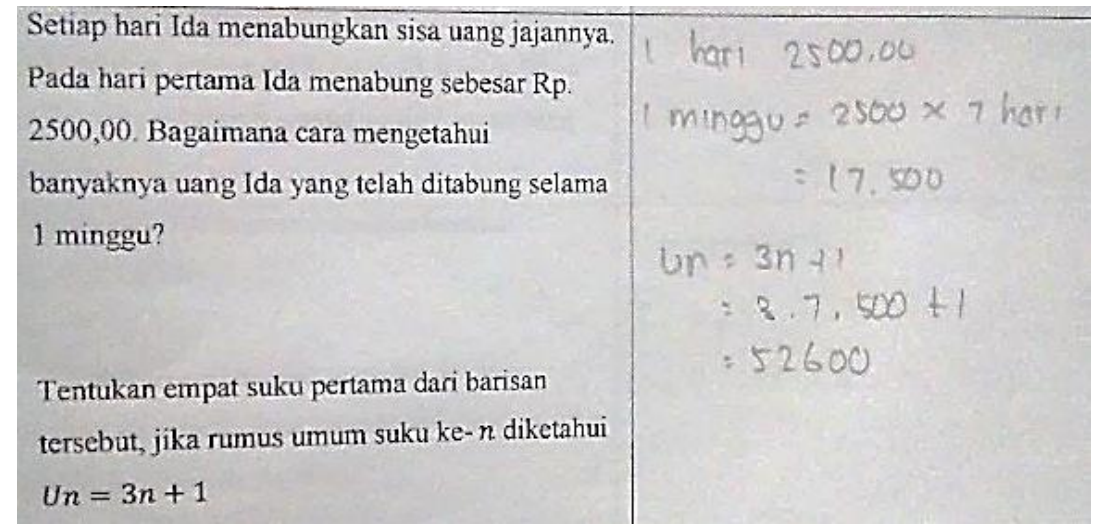

Gambar 15. Jawaban S3 Soal 6 dan 7 
S3 hanya dapat menjawab soal nomor 6 dengan baik, walaupun tidak menerapkan konsep barisan dan deret. Sedangkan untuk soal nomor 7, S3 tidak teliti dalam membaca soal. Hal ini terlihat dari jawaban siswa yang justru mensubstitusi angka 4 pada rumus tersebut, seharusnya S3 mencari empat suku pertama dari barisan tersebut. Berikut hasil wawancara dengan S3:

G : "Mengapa kamu tidak menerapkan konsep barisan dan deret pada sol nomor 6? Mengapa kamu mensubstitusi angka 4 pada soal nomor 7?"

S3 : "Iya bu, aku tadinya mikir tinggal dikaliin aja, lupa gak dipake konsepnya bu. Kalau nomor 7 mah aku salah baca soal bu aku pikir kalau yang dicari itu suku keempat."

G : : "Lain kali harus lebih teliti lagi ya baca soalnya."

Dalam penelitian ini, siswa berkemampuan matematika tinggi hanya memenuhi 3 dari 5 indikator berpikir kritis, yaitu indikator 1, 2, dan 5. Dengan kata lain, siswa berkemampuan tinggi mampu merumuskan masalah dengan tepat, mampu memberikan argumen dengan tepat, dan mampu mengambil kesimpulan dengan tepat. Hal ini sesuai dengan penelitian Yanti dan Prahmana (2017) yang menyatakan bahwa seseorang yang memiliki kemampuan berpikir matematis, yaitu memiliki kemampuan intelektual dengan berpikir logis dan reflektif dalam memahami permasalahan matematika, menganalisis permasalahan, dan memutuskan solusi dengan tepat.

Siswa berkemampuan matematika sedang hanya memenuhi 3 dari 5 indikator berpikir kritis, yaitu indikator 1, 3, dan 5. Dengan kata lain, siswa berkemampuan sedang mampu merumuskan masalah dengan tepat, menentukan deduksi dan induksi dengan tepat walaupun hanya coba-coba, dan mengambil kesimpulan dengan tepat. Hal ini sesuai dengan pernyataan Ilma, Hamdani, dan Lailiyah (2017) bahwa sebelum siswa memiliki kemampuan menganalisis, terlebih dahulu harus memiliki kemampuan mengingat, memahami, dan menerapkan dengan baik. Kemampuan menganalisis yang baik merupakan salah satu indikator berpikir kritis.

Siswa berkemampuan matematika rendah hanya memenuhi 2 dari 5 indikator berpikir kritis, yaitu indikator 1 dan 5. Dengan kata lain, siswa berkemampuan rendah mampu merumuskan masalah dengan tepat dan mampu mengambil kesimpulan, walaupun kesimpulan yang diambil belum tepat. Berdasarkan hal tersebut, maka dapat disimpulkan bahwa kemampuan berpikir kritis siswa masih rendah. 


\section{SIMPULAN DAN SARAN}

Berdasarkan hasil dan pembahasan, dapat diambil beberapa simpulan mengenai kemampuan berpikir kritis siswa pada konsep barisan dan deret, yaitu: 1) siswa dengan kemampuan matematika tinggi kurang lengkap dalam menjelaskan dan menyelesaikan masalah, belum bisa memberikan penjelasan yang relevan, belum dapat menyelesaikan masalah, belum dapat mengevaluasi jawaban, dan belum dapat mengaplikasikan konsep; 2) siswa dengan kemampuan matematika sedang kurang lengkap dalam menjelaskan dan menyelesaikan masalah, belum bisa memberikan penjelasan yang relevan, belum dapat menyelesaikan masalah, belum dapat mengevaluasi jawaban, dan belum dapat mengaplikasikan konsep; dan 3) siswa dengan kemampuan matematika rendah juga kurang lengkap dalam menjelaskan dan menyelesaikan masalah, belum bisa memberikan penjelasan yang relevan, belum dapat menyelesaikan masalah, belum dapat mengevaluasi jawaban, dan belum dapat mengaplikasikan konsep.

Berdasarkan hasil dan pembahasan di atas menunjukan bahwa rata-rata tingkat kemampuan berpikir kritis matematis siswa SMK masih tergolong rendah pada hampir semua indikator berpikir kritis. Untuk itu perlu diberikan beberapa soal yang membiasakan siswa berpikir kritis agar kemampuan siswa menyelesaikan soal berpikir kritis menjadi meningkat.

\section{DAFTAR PUSTAKA}

Fisher, A. (2009). Berpikir kritis: Sebuah pengantar. Jakarta: Erlangga.

Hendriana, H., Rohaeti, E. E., \& Sumarmo, U. (2017). Hard skill dan soft skill matematik siswa. Jakarta: Refika Aditama.

Hidayat, W. (2012). Meningkatkan kemampuan berpikir kritis dan kreatif matematik siswa SMA melalui pembelajaran kooperatif think-talk-write (TTW). Prosiding Seminar Nasional Penelitian (UNY).

Ilma, R., Hamdani, A. S., \& Lailiyah, S. (2017). Profil berpikir analitis masalah aljabar siswa ditinjau dari gaya kognitif visualizer dan verbalizer. JRPM (Jurnal Review Pembelajaran Matematika, 2(1), 1-14. doi: https://doi.org/10.15642/jrpm.2017.2.1.1-14.

Istianah, E. (2013). Meningkatkan kemampuan berpikir kritis dan kreatif matematik dengan pendekatan model eliciting activities (MEAS) pada siswa SMA. Infinity Journal, 2(1), 43-54. doi: http://dx.doi.org/10.22460/infinity.v2i1.23 
Jumaisyaroh, T., Napitupulu, E., \& Hasratuddin, H. (2015). Peningkatan kemampuan berpikir kritis matematis dan kemandirian belajar siswa SMP melalui pembelajaran berbasis masalah. Kreano, Jurnal Matematika Kreatif-Inovatif, 5(2), 157-169. doi:https://doi.org/10.15294/kreano.v5i2.3325

Mahmuzah, R., Ikhsan, M., \& ., Yusrizal. (2014). Peningkatan kemampuan berpikir kritis dan disposisi matematis siswa SMP dengan menggunakan pendekatan problem posing. Jurnal Didaktik Matematika, 1(2), 43-53.

Purmawidyani, M. (2017). Pembelajaran matematika menggunakan pendekatan problem based learning untuk meningkatkan kemampuan berpikir kritis matematis siswa SMP. Skripsi Tidak Dipublikasikan. Bandung: Program Studi Pendidikan Matematika, STKIP Siliwangi

Purwanto, M. (2007). Psikologi pendidikan. Bandung: PT Remaja Rosdakarya.

Yanti, O. F. \& Prahmana, R. C. I. (2017). Model problem based learning, guided inquiry, dan kemampuan berpikir kritis matematis. JRPM (Jurnal Review Pembelajaran Matematika, 2(2), 120-130. doi: https://doi.org/10.15642/jrpm.2017.2.2.120-130. 